\title{
TAMAR, RAHAB, RUTH, AND MARY - THE BOLD WOMEN IN EPHREM THE SYRIAN'S HYMN DE NATIVITATE 9
}

\author{
Phil J. Botha \\ (University of Pretoria)
}

\begin{abstract}
Ephrem the Syrian's hymn De Nativitate 9 is translated and its structure and the presence and function of various literary tropes in it are discussed. It is concluded that the most important polarities in the hymn are those between Christ's divinity and his humanity, between fear and love, between impurity and holiness, and between symbol and truth. It is argued that the purpose of the hymn was to instil awe for the wonder of Christ's birth from a woman, but also to encourage Christians in fourth century Syria to emulate the bold dedication of women like Tamar, Rahab, and Ruth to Christ alone, and to provide answers to Jewish criticism and ridicule of the virgin birth of Christ.
\end{abstract}

\section{Introduction}

In his ninth hymn on the nativity of Christ, Ephrem the Syrian (ca. 306-373 C.E.) mentions three conspicuous female figures from the Old Testament together in one breath: Tamar, Rahab, and Ruth. In the words of Mary, the mother of Jesus, Ephrem describes them in this hymn as women who have "hurried after men" for the sake of Christ. They are probably mentioned together in this hymn because their names appear (together with Bathsheba, "the wife of Uriah") in the genealogy of Jesus in Matthew 1. Writing a hymn for the celebration of the Epiphany of Jesus, ${ }^{1}$ Ephrem is in a certain sense giving a sermon on the genealogy of the Messiah in Matthew 1.

The inclusion of women in the genealogy of an important male person is a novelty in the context of Jewish genealogies. ${ }^{2}$ In Matthew 1 this was probably meant to highlight the providential aspect of the birth of Jesus. It would prove that irregularities such as the involvement of non-Israelites and even aberrations of sexual passion ${ }^{3}$ could be included and vindicated by God in the creation of a perfectly regular genealogy (in symbolic segments of 14 generations) with the purpose of establishing a new people for himself from both Israelites and non-Israelites. ${ }^{4}$ But although Jewish genealogies usually did not include women, the positive attitude towards these three in the early Christian tradition was probably based on Jewish Messianic interpretations already in existence before the Gospels were 
written. Tryggve Kronholm has shown that Ephrem's exegesis of the story about Judah and Tamar in Genesis 38 corresponds in many respects to the interpretation found in rabbinic sources. ${ }^{5}$ According to Kronholm, the interpretation of the story of Judah and Tamar as a story of "holy adultery" is an early Christian tradition "rooted in a Messianic exegesis prevalent in ancient Judaism, as preserved particularly in the rabbinic sources, despite the fact that some of the relevant dicta derive from rabbis of the $4^{\text {th }}$ century C.E. and that several of the sources were compiled after the time of Ephraem Syrus". Ephrem thus also knew and made use of various elements of Jewish Messianic interpretation of the story about Judah and Tamar.

I made a similar comparison between Ephrem's treatment of Tamar and the treatment she received in Jewish exegetical sources. ${ }^{7}$ My primary concern was with Ephrem's views in his prose commentary on Genesis, while Kronholm directed his attention in the first place towards Ephrem's hymns. ${ }^{8}$ I also found the two exegetical traditions (rabbinic and that of Syriac-speaking Christianity) to be conspicuously similar, but pointed out the differences in focus between the two traditions: the rabbis saw Judah as an exemplary figure for their own generation while Ephrem saw Tamar as the exemplary figure in this story. The rabbis also inverted the pronouncement in the Bible about Judah not afterwards again having intercourse with Tamar to imply that he did not stop having intercourse with her, while Ephrem made both Tamar and Judah representatives of the Syriac proto-monastic ideal of abstaining from sex after this one incident of "holy adultery".

The aim of this article is different from that of the above-mentioned two. I am not so much interested here in the Jewish sources of Ephrem's interpretation or in the differences between his views of Tamar and the other women and those of the rabbis, but would like to establish what message Ephrem tried to convey to Syriac speaking Christianity with the composition of this hymn and what strategies he used to reach that goal. After reading Kees den Biesen's book "Simple and Bold" on Ephrem's theology, ${ }^{9}$ I became aware of the importance attached to "boldness" in this song. It seems that the women mentioned in this hymn, Tamar, Rahab, and Ruth, but also Mary, the mother of Jesus-who is implicitly includedshare this one trait of "boldness". They all chose to despise shame for the sake of the Messiah, ${ }^{10}$ to be bold and to endeavour each to form a link in the chain of the genealogy of Christ. 
It thus seems that Ephrem is arguing here that Christ's birth as a human was made possible by the visionary and bold love a number of women had for him. He shows that the sexual aberrations of Tamar and Ruth are in fact vindicated by their pure motive of love for the Messiah, and that they were rewarded by Christ for this. Ephrem's intention with the hymn therefore probably was to instil adoration for Christ at the commemoration of his birth, awe for the miraculous way in which his birth was prefigured and prophesied in the Old Testament, and a desire to imitate the bold dedication of those women who offered themselves to make his birth possible and who were thus Old Testament precursors of Mary. The techniques he uses to achieve this include figures of speech such as repetition, alliteration, rhyme, parallelism, chiasmus, rhetorical questions, paradox, antithesis, wordplay, synecdoche, metaphor, and simile. Many of these figures serve to construct polarities which reflect the deep structure of his theological thinking and are consequently used to enhance the implicit and explicit arguments he constructs. ${ }^{11}$

A proper procedure for the investigation would perhaps be to analyse the literary and rhetorical features and the structure of the hymn comprehensively. This was indeed done, but constraints of space will not allow a complete discussion of the results. The full Syriac text and a rather literal translation are provided. Prominent polarities in the hymn are subsequently discussed with reference to the literary techniques Ephrem employed to construct them and the arguments he conducts through them. The merit of the above-mentioned hypothesis is argued in conclusion.

\section{Translation of Ephrem's madrâšâ or "Teaching Song” De Nati- vitate 9}

We are privileged to have available today, in addition to the German translation made by Edmund Beck, ${ }^{12}$ also the English translation of Kronholm of part of the song (stanzas 7 to13) ${ }^{13}$ and the English translation of Kathleen McVey, ${ }^{14}$ all based on the text edition of Beck. ${ }^{15}$ These translations were consulted, but not necessarily followed in preparing the translation below.

\section{De Nativitate 9}

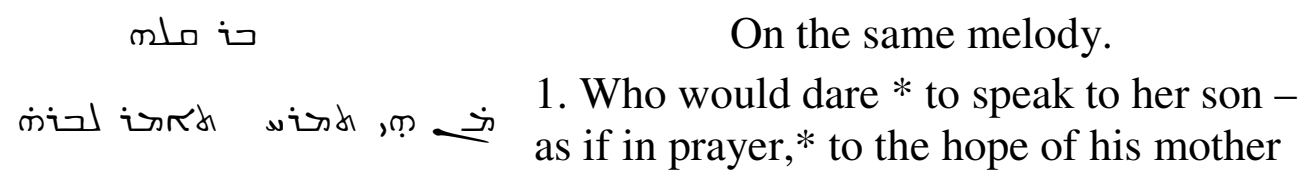




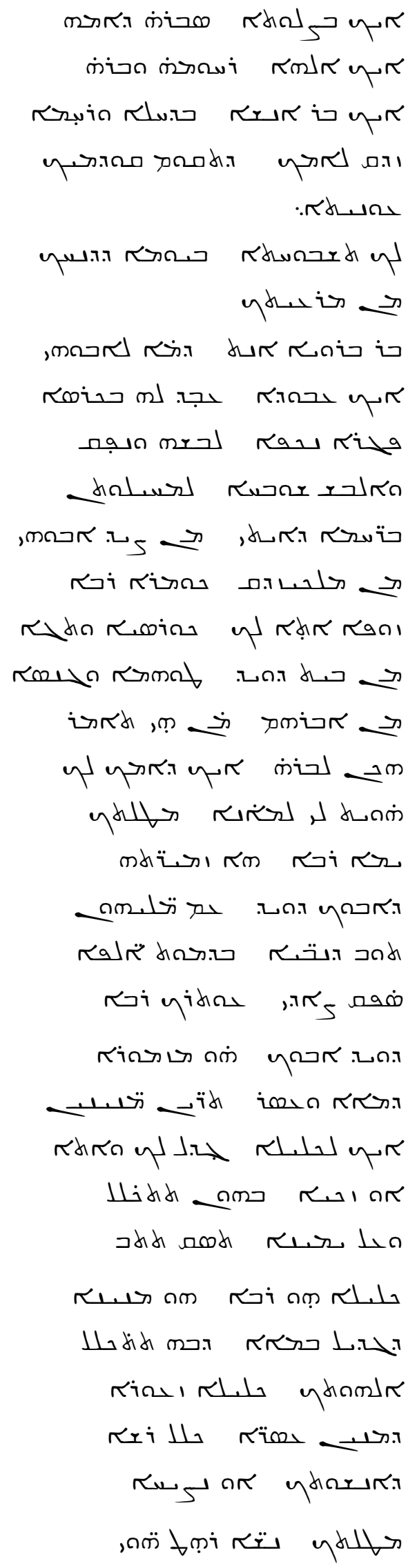

- as God; * to her beloved (child) and her son - as a human? $*$ In dread and love - it is fitting for your mother * to stand before you.

\section{Response:}

To you be the praise * on the day of your manifestation (Epiphany) ${ }^{16} *$ to your flock!

2. You are the Son of the Creator, * who is like his Father. - As Creator * he created for himself in the womb - a chaste body. * He put it on and went out, - and clothed with glory * our weakness - through the grace which he brought * from his Father.

3. From Melchizedek, * the high priest the hyssop came to you, * a throne and a diadem - from the house of David; * family and descent - from Abraham. * Who would speak - in this way to her son * as your mother to you?

4. "I became a harbour * for your sake, O great Sea! * See, the Psalms - of your father David * with the words - of the prophets also, * like ships - he emptied out at me: * your great wealth."

5. David, your father, * that psalm - of a hundred and ten, * the two numbers, - like a crown $*$ he wove and brought to you $;{ }^{17}$ O Triumphant One! * You will be crowned with them - and on the righthand side * you will ascend and seat yourself.

6. A big crown * is that number - that is woven with the hundred, * with which is crowned - your divinity. ${ }^{*}$ The small crown, - from the number ten, * has crowned the head - of your humanity, * $\mathrm{O}$ Victorious One!

7. On your account $*$ women have hurried - after men: * Tamar desired - a man who 


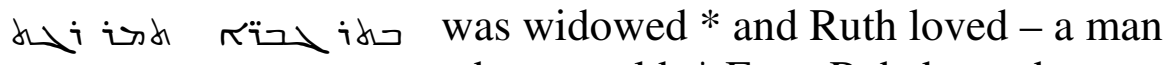

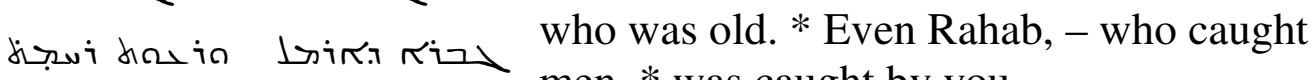

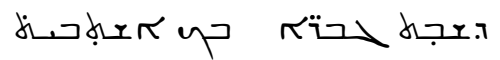

$$
\begin{aligned}
& \text { 8. Tamar went out * and in darkness - }
\end{aligned}
$$

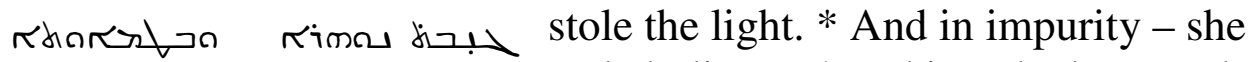

$$
\begin{aligned}
& \text { stole holiness, * and in nakedness - she } \\
& \text { secretly entered (she stole and entered)* }
\end{aligned}
$$

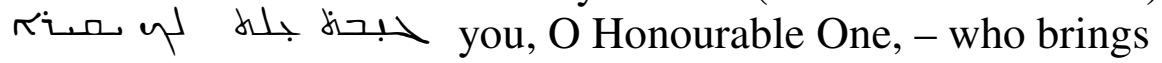

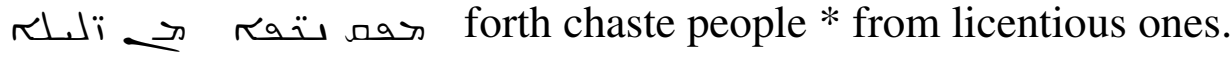

$$
\begin{aligned}
& \text { ฤmin } \\
& \text { - to prevent (it). * He mentioned the } \\
& \text { (death) penalty, - but she did not become }
\end{aligned}
$$

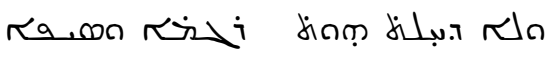

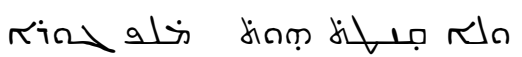

$$
\begin{aligned}
& \text { תחס }
\end{aligned}
$$

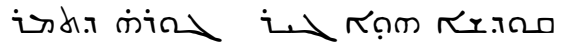

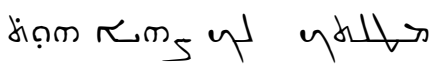

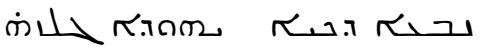

$$
\begin{aligned}
& \text { rotum }
\end{aligned}
$$

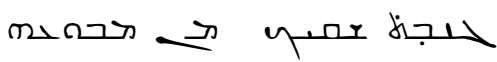

$$
\begin{aligned}
& \text { ydla sulation }
\end{aligned}
$$

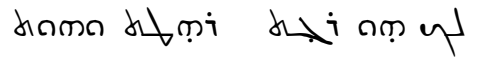

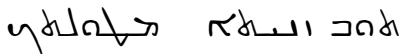

$$
\begin{aligned}
& \text { dinmo dity duno am us }
\end{aligned}
$$

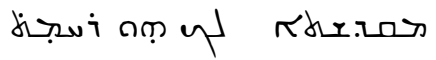

$$
\begin{aligned}
& \text { पida dis ז } \\
& \text { isd rivd } \\
& \text { ד }
\end{aligned}
$$

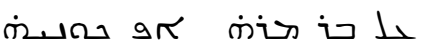

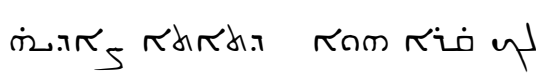

$$
\begin{aligned}
& \text { קף } \\
& \text { דובר כهلم } \\
& \text { כ经 }
\end{aligned}
$$

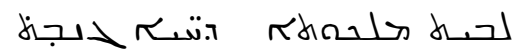

$$
\begin{aligned}
& \text { afraid; * stoning and sword, - but she did } \\
& \text { not become terrified. } * \text { The teacher of } \\
& \text { adultery - was forbidding adultery * so as } \\
& \text { to restrain you! } \\
& \text { 10. For it was a holy thing, * the adultery } \\
& \text { of Tamar, - for your sake. * She was } \\
& \text { thirsting for you, - the Pure Spring. * } \\
& \text { Judah cheated her - from your drink. * } \\
& \text { The dried-up spring - stole your drink* } \\
& \text { from his fountain. } \\
& \text { 11. She became a widow * for your sake. } \\
& \text { - It was you whom she coveted; * she ran } \\
& \text { and became - even a whore * for your } \\
& \text { sake. - It is you whom she earnestly de- } \\
& \text { sired. * She guarded (herself) and she be- } \\
& \text { came * consecrated. }{ }^{19} * \text { It is you whom } \\
& \text { she loved. } \\
& \text { 12. Let Ruth hear the good news, * for she }
\end{aligned}
$$




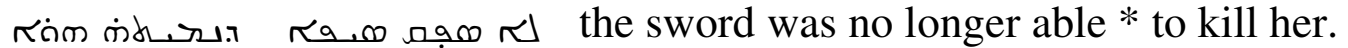

$$
\begin{aligned}
& \text { (2. Ruth: with a man * on the threshing } \\
& \text { ח floor she lay down, - for your sake. * Her }
\end{aligned}
$$

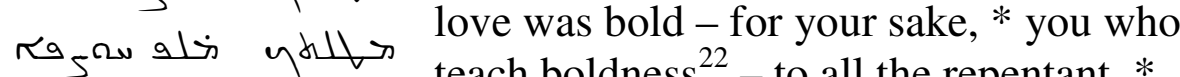

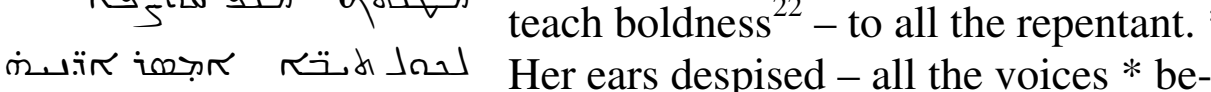

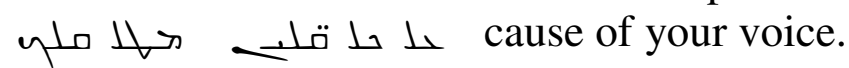

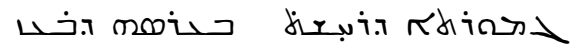

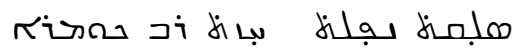

$$
\begin{aligned}
& \text { דring }
\end{aligned}
$$

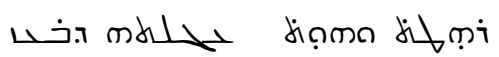

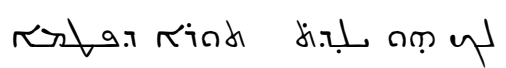

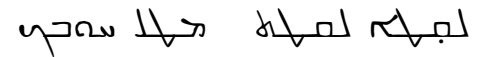

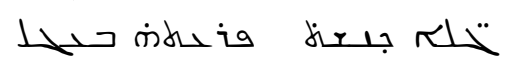

$$
\begin{aligned}
& \text { مله } \\
& \text { ملحس }
\end{aligned}
$$

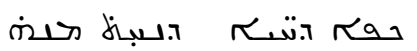

\section{The structure of the hymn}

The structure of this hymn can be portrayed as follows:

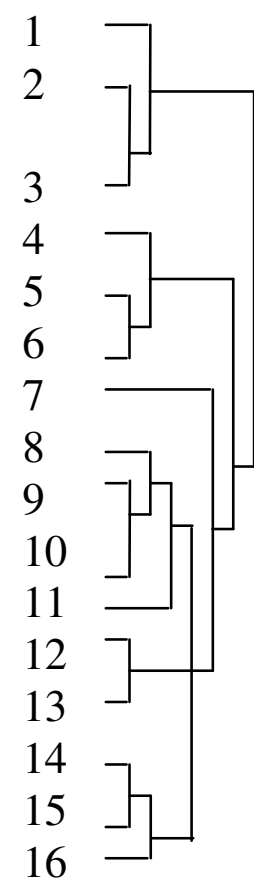

Christ is God and man; Mary experiences dread and love

Christ is Creator, he created a pure body, and clothed himself to clothe our weakness

Christ is heir to Melchizedek, David, and Abraham

Mary a harbour; Psalms, Prophets are ships offloading symbols

Ps 110 presents two crowns to Christ:

"100" signifies his divinity; "10" signifies his humanity

Tamar, Ruth, and Rahab ran after men for the sake of Christ

Tamar did wrong, but her motive made it right

Tamar conquered fear through love

Tamar committed "holy adultery"

Tamar suffered degradation for Christ to attain consecration

Ruth and Tamar's names are symbolic, pointing to Christ

Honourable women made themselves contemptible for Christ

Ruth suffered degradation for the sake of Christ

Ruth saw Christ and contributed towards his birth

Ruth was rewarded for her humiliation by giving birth to kings 
The first three stanzas of the madrâšâ serve as an introduction in which Ephrem seems to introduce Mary, the mother of Jesus, as the first person speaker of stanzas $4-16 .{ }^{23}$ In it, he addresses Christ and speaks to him about the way his mother, Mary, speaks to him. This section (stanzas 1-3) is also demarcated from the rest by the use of an introductory rhetorical question right at the beginning ("Who would dare to speak...?") and by the insertion of another, corresponding one at the end of the third stanza ("Who would speak...?"). The two questions seem to form an inclusio which embraces stanzas 1-3. The implied answer to the two rhetorical questions is "No one", and this is meant to warn against careless speaking about Christ on the one hand, while it simultaneously focuses on the special relationship between Mary and Jesus on the other. ${ }^{24}$ The words of stanza 4, a direct address once again to Christ, only make sense in the mouth of Mary, so that a new section must start here.

Stanzas 4-16 are characterised by the repetition of "for your sake" or "on your account". It occurs in stanza 4 (concerning Mary), stanza 7 (concerning Tamar, Ruth, and Rahab), stanza 10 (concerning Tamar), stanza 11 (twice, concerning Tamar), and stanza 14 (twice, concerning Ruth). This very dominant feature is strengthened by the phrase "through you" in stanza 13 and by the words "because of your voice" in stanza 14. In these stanzas, Mary, Tamar, Rahab, and Ruth are thus united in the description of their doing something "for the sake of" Christ. Mary became a "harbour" for his sake into which the "ships" of the Psalms and the Prophets came to offload Christ's "great wealth" consisting of the prophetic promises. The other three women all "hurried after men" (stanza 7) "for the sake of Christ". Ephrem focuses especially on Tamar (stanzas 8-13) and Ruth (stanzas 12 and 14-16). He describes the "boldness" of these women who despised shame and ventured into illicit relationships "for the sake of" Christ (although the word "boldness" itself is used only for a description of the conduct of Ruth in stanza 14). Tamar and Ruth are both also described as women who suffered degradation or humiliation for the sake of Christ (cf. stanzas 13, 14, and 16). This particular hymn says nothing about Mary's humiliation for the sake of Christ, but it is something that is mentioned in the sixth hymn of the cycle (De Nat 6:3-5). ${ }^{25}$

\section{Binary opposition and polar thought-patterns}

Antithetic parallels and other forms of semantic and semiotic opposition constitute such a large segment of all parallels in Ephrem's work, that it would be justifiable to suppose that such forms of stylistic opposition are 
merely the manifestation of polar thought-patterns in the deep structure of his theological thinking. I would like to suggest that the vast difference between God and creation, the most fundamental polarity in Ephrem's thinking, has also dictated the construction of various forms of antithesis in this hymn. But antitheses are also used in this hymn to formulate the tension between symbol and reality and especially between licentious and chaste behaviour, showing that the conduct of Tamar and Ruth was vindicated by the purity of their intentions. Among the forms of antithesis used argumentatively in this hymn are semantic opposition, semiotic opposition, active versus causative constructions, active versus passive constructions, and positive statements versus negations of the same.

\subsection{The polarity God versus humanity and the consequent opposition of fear and love}

The polarity God versus humanity plays an important role in the first six stanzas of this song. It is the awareness of the chasm between humanity and God-and the realisation that it has been bridged by God out of love for humanity-that gives rise to another polarity expressed already in the first stanza of this hymn: the polarity "fear" versus "love". When one becomes aware of God's majesty, fear and dread are the natural reactions. But "fear" should be matched (or balanced) by "love" as two opposite but also complementary forces that compete to dictate the actions of a believer. In the first stanza, Ephrem notes that it is fitting for Jesus' mother to stand before him "in dread and love". That God became a human, the son of a loving mother, is a paradox. As he is very fond of doing, Ephrem marks this paradox with the help of a rhetorical question:

1. Who would dare * to speak to her son - as if in prayer,* to the hope of his mother - as God; * to her beloved (child) and her son - as a human? * In $\underline{\text { dread }}$ and love - it is fitting for your mother

* to stand before you.

The binary pairs in this first stanza can be schematised as follows:

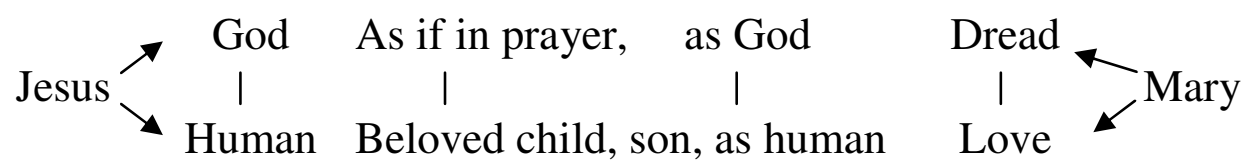

The aspects of Jesus' divinity and his humanity are then worked out in stanzas 2 to 6 . In stanza 2 he is described as "Son of the Creator" (thus not 
only the son of Mary as in stanza 1). As Creator he created for himself a chaste body in the womb, put it on and went out (he was thus born as a human) in order to clothe our weakness with the glory which he brought from the Father (his divine aspect).

2. You are the Son of the Creator, * who is like his Father. - As Creator $*$ he created for himself in the womb - a chaste body. * He put it on and went out, - and clothed with glory * our weakness - through the grace which he brought * from his Father.

In stanza 3, synecdoche ${ }^{26}$ is used to draw attention to his divine descent from "Melchizedek" (as eternal priest) on the one hand ${ }^{27}$ and his human descent from David and Abraham on the other:

3. From Melchizedek, * the high priest - the hyssop came to you, * a throne and a diadem - from the house of David; * family and descent - from Abraham. * Who would speak - in this way to her son * as your mother to you?

In stanzas 4-6, Ephrem (in the words of Mary) focuses on another aspect of Ps 110 , a psalm which was already alluded to in stanza 3. It is said that David, Jesus' human "father" (stanzas 4 and 5) witnessed to both his divinity and his humanity by composing Ps 110 . The number of the psalm itself is metaphorically interpreted as two crowns which David "wove and brought" to Christ: the number 100 testifying to his divinity and the number 10 to his humanity. ${ }^{28}$ With these two crowns (Mary says to her son) he will be crowned and ascend to be seated on the right-hand side of God (another allusion to the contents of Ps 110): ${ }^{29}$

4. "I became a harbour * for your sake, - O great Sea!* See, the Psalms - of your father David * with the words - of the prophets also, * like ships - he emptied out at me: * your great wealth."

5 . David, your father, * that psalm - of a hundred and ten, * the two numbers, - like a crown $*$ he wove and brought to you; - $\mathrm{O}$ Triumphant One! * You will be crowned with them - and on the right-hand side * you will ascend and seat yourself.

6. A big crown $*$ is that number - that is woven with the hundred, * with which is crowned - your divinity. * The small crown, - from the number ten, $*$ has crowned the head - of your humanity, $* \mathrm{O}$ Victorious One! 
The dominant theme in the first six stanzas therefore seems to be the ambivalence experienced by Mary, the mother of Jesus, because of his divinity and his humanity. On the one hand she was related to him as the loving mother of a first-born (human) son; on the other she actually had to address him as if in prayer, as God who became man. This caused "dread" which competed with the "love" she felt for him.

The dialectic between "dread" and "love" plays a role in the rest of the hymn as well, but it is from here on only indirectly based on the polarity between God and humanity. The love which the women in the genealogy of Jesus in Matthew 1 displayed for Christ is a central theme of stanzas 7-16 indeed. But the dread or the fear that they experienced was not a tremens for God in the first place. It was fear for the punishment, degradation, and shame they would have to face when they would "hurry" or "rush" to become part of Jesus' line of human descent. ${ }^{30}$ The verb "to love" $(\mathrm{rhm})$ is used in stanza 7 of Ruth who "loved" an old man for the sake of Christ and in stanza 11 of Tamar who "loved" Christ (cf. the cognate nouns rhwm' "beloved" and rhm' "love" in stanza 1 with regard to Mary), while the noun $h w b$ ' "love" is used twice for the dedication Ruth displayed towards Christ (stanzas 14 and 16). The word for "dread" in stanza 1 is $d h l$ '. This stem reappears as a verb in stanza 9, where a beautiful polarity is constructed between Satan and Tamar:

9. Satan saw him * and feared and rushed - to prevent (it). ${ }^{*} \mathrm{He}$ mentioned the (death) penalty, - but she did not become afraid; * stoning and sword, - but she did not become terrified. * The teacher of adultery - was forbidding adultery* so as to restrain you!

Satan saw that Christ might be born from Judah's descendents, therefore he "feared (qnt) and rushed to prevent it" (cf. Tamar's "rushing" after Judah, alluded to in stanza 7). Satan consequently mentioned the death penalty as a threat to Tamar, but she did not become afraid $(d h l)$; he mentioned stoning and sword, but she did not become terrified (qnt). The roles are ironically inverted here: Satan fears the birth of Christ and rushes to prevent it; Tamar does not fear the punishment for adultery and rushes to make it possible. This means that "the teacher of adultery was forbidding adultery so as to restrain you" (stanza 9, end). The irony of this last antithesis is emphasised through a chiastic arrangement of elements: 
The teacher of adultery :: $\underline{\text { adultery }}$ was forbidding

A $\quad$ B $\quad$ B $\quad$ A

It thus turns out that Tamar overcame her fear (of God, who is represented by the punishment for adultery mentioned in his Torah) through love for Christ.

The same is true of Ruth, by implication. In stanza 14 Ephrem says that "her love was bold for your sake, you who teach boldness to all the repentant". When one realises that "boldness" is described elsewhere by Ephrem as the positive attitude that overcomes fear, ${ }^{31}$ it becomes clear that Ruth similarly had to conquer her respect for the Torah (which forbids fornication), and for the ridicule and gossip (which served in Ancient Israel as social control to uphold respect for God's Torah) through her love for Christ.

14. Ruth: with a man * on the threshing floor she lay down, - for your sake. * Her love was bold - for your sake, * you who teach boldness - to all the repentant. * Her ears despised - all the voices $*$ because of your voice.

Ruth's "boldness" is described as follows: "Her ears despised all the voices because of your voice". Chiasmus is once again used to emphasise the "inverted quality" of Ruth's dedication that ignored the gossip. ${ }^{32}$ Ephrem also mentions the "humiliation" Ruth suffered out of love for Christ (stanza 16) and includes her in the description of "honourable women" who became "contemptible" through Christ (stanza 13). In a sense, Tamar and Ruth displayed the same "boldness" as the blind man who sat along the road where Jesus passed. He ignored those who would restrain his cry for help: "The crowd rebuked him so he would keep silent, but he cried out all the louder and his boldness pleased his Redeemer". ${ }^{33}$

In addition to its function of serving as an instrument of praise for the Saviour at the commemoration of his birth, ${ }^{34}$ this hymn therefore also seems to applaud the dedication ("boldness") of the women who form part of his genealogy. Their love for Christ certainly was something which was commended by Ephrem with the purpose of encouraging a similar kind of dedication among the men and women in his audience. But because the love of these biblical heroines for Christ was manifested as a seeming desire for sexual union with men ("rushing after men"), Ephrem expends a considerable amount of space in this hymn to prove the noble ulterior 
quality of the motives of Tamar and Ruth, and also the divine sanction given for their behaviour. He also uses symbolic interpretation to prove the divine commission of their involvement in the genealogy of Jesus. It is not stated explicitly in this particular hymn, but the focus on these women and their humiliation for the sake of Christ was probably also meant to defend the Christian doctrine of the virgin birth against Jewish ridicule. Tamar and Ruth thus stand in defence of Mary as well. ${ }^{35}$

\subsection{The polarity impurity versus holiness}

In stanza 7, Ephrem argues that Tamar and Ruth "hurried" or "rushed" after men for the sake of Christ and not for their own sake. He finds proof of this statement in the fact that Tamar sought a man who was widowed and Ruth one who was old:

7. On your account * women have hurried - after men: * Tamar desired - a man who was widowed * and Ruth loved - a man who was old. * Even $\underline{\text { Rahab }},-$ who caught men, * was caught by you.

According to the biblical text, Ruth was indeed praised by Boas for "not going after young men" (Ruth 3:10). Ephrem cannot say that Rahab, who also hurried after men, did this for the sake of Christ. She actually plays a very limited role in this hymn, but it is to the credit of Ephrem that he does not simply ignore her. She is incorporated into the scheme by modifying the parallel between Tamar and Ruth to show that she was a sinner at first, but was converted to a chaste life through her faith in Christ:

\begin{tabular}{|c|c|c|c|}
\hline $\begin{array}{c}\text { A } \\
\text { Tamar } \\
\text { Ruth }\end{array}$ & $\begin{array}{c}\text { B } \\
\text { desired } \\
\text { loved }\end{array}$ & $\begin{array}{c}\mathrm{C} \\
\text { a man } \\
\text { a man }\end{array}$ & $\begin{array}{c}\text { D } \\
\text { who was widowed } \\
\text { who was old } \\
\end{array}$ \\
\hline $\begin{array}{c}\text { Rahab } \\
\text { A }\end{array}$ & $\frac{\mathrm{cal}}{\mathrm{B}}$ & $\begin{array}{c}\text { men } \\
\mathrm{C}\end{array}$ & $\begin{array}{r}\text { y you) was ce } \\
-C\end{array}$ \\
\hline
\end{tabular}

Rahab thus forms a loose parallel to Tamar and Ruth (elements A, B, and C being present), but her case is characterised by an internal chiastic antithesis composed with the help of an active/passive construction and the insertion of an agent (by you). The effect of this is to show that, although she at first "caught" men, she "was caught" by Christ and thus turned around to become consecrated to him alone. 
In stanza 8, Ephrem uses a special technique to argue that Tamar was justified in what she did:

8. Tamar went out $*$ and in darkness - stole the light. * And in impurity - she stole holiness, ${ }^{*}$ and in nakedness - she secretly entered (she stole and entered)* you, O Honourable One, - who brings forth chaste people * from licentious ones.

In this case he is also in line with the biblical text, since Judah vindicates Tamar by declaring "she is more righteous than I" (Gen 38:26). The technique Ephrem uses here is to illustrate that negative times negative produces positive:

A-

in darkness

in impurity

in nakedness
B-

she stole

she stole

she stole and entered you, the Honourable One

The first element (with a negative connotation) is transformed into its absolute antonym with a positive connotation through the repeated use of "steal". Because it was done on behalf of Christ, her secret transgression is shown to be a transparent virtue. Christ is further described in the last line as the one "who brings forth chaste people from licentious ones". In this way another clever antithesis is created: Tamar "went out" to do these things so that she could secretly "enter" Christ, who "brings out" chaste people from licentious ones. Since she went out with the sole purpose of "entering" Christ, her deed was transformed from darkness to light and from impurity to holiness, while she herself was transformed from being licentious into a chaste person. While the semiotic pattern of the whole stanza is negative-negative-positive, that of the last line (which refers to Christ) is positive-positive-negative. This chiasmus of connotative values seems to emphasise the transforming power of Christ.

The thrust of the arguments in stanzas 10, 11, and 13 is also that Tamar's adultery was holy since it was done for the sake of Christ:

10. For it was a holy thing, * the adultery of Tamar, - for your sake. * She was thirsting for you, - the Pure Spring. * Judah cheated her - from your drink. * The dried-up spring - stole your drink * from his fountain. 
11. She became a widow * for your sake. - It was you whom she coveted; $*$ she ran and became - even a whore * for your sake. It is you whom she earnestly desired. * She guarded (herself) and she became ${ }^{*}$ consecrated. * It is you whom she loved.

In stanza 10, Ephrem metaphorically describes the seed of the Messianic line as water. Tamar, a dried-up spring, was thirsting for Christ, the Pure Spring, but Judah cheated her from it. She consequently "stole" the drink of Christ from his (Judah's) fountain. Stanza 11 comprises of a complex three-fold parallel in which the third part forms an antithesis to the first two:

She became

A

she hurried and became

$\frac{\text { A- }}{\text { she guarded herself }}$

and became

A+ a widow for your it is

B $\quad C \quad D$

even a for your it is

whore

Bsake you

C D

whom she coveted

consecrated

$\mathrm{B}+$

it is

you
E+ whom she earnestly desired

whom she loved

D E+

From the first to the second parallel, there is a Steigerung, since the neutral remark of the first pronouncement that she became a widow is intensified with "hurried" (which carries a negative connotation in this context) in the second one and by changing the neutral "a widow" into "a whore" (which is strongly negative). But all of this is overturned with the last, antithetic, parallel which states that she "guarded herself" and became "consecrated". It is known that Ephrem represented both Tamar and Judah as forerunners of the Syrian proto-monastic ideal of becoming an ihidâyâ or qaddišâ. ${ }^{36}$ Repetition of the idea that it was only Christ whom she coveted, desired, and loved, hammers in the idea expressed in the third part of the parallelism that she was from the beginning only dedicated to the Saviour. This constitutes a strong argument that what she did was honourable and that her dedication deserves to be imitated.

\subsection{The polarity symbol versus truth}

A last set of arguments concerning the virtue of Tamar's deed is offered in stanza 13: 
13. Through you they became contemptible, * the honourable women, - (you) who teach all to be chaste. * You are the one whom she (Tamar) stole - at the crossroads, * the One who treads out the way - to the kingdom. * Since she stole life, - the sword was no longer able * to kill her.

After repeating the previous arguments that Tamar (and Ruth) as honourable women became contemptible for the sake of Christ who teaches all to be chaste, Ephrem says that Tamar "stole" Christ at the "crossroads" (in Syriac "the house of the ways"). But Christ, whom she stole, is the One who treads out the "way" to the "kingdom" (in Syriac "the house of kingship"). That Tamar waited at the crossroads is thus interpreted as a symbol of the fact that she did this to find the way to the kingdom. ${ }^{37} \mathrm{He}$ concludes the stanza by stating that she actually "stole" life and that that was the reason why the "sword" could not kill her. The fact that she was not stoned as the Torah requires, is thus taken as proof of the fact that she did this for the sake of Christ.

Symbolic arguments are also employed in stanza 12:

12. Let Ruth hear the good news, * for she sought your riches. Moab entered into it. * Let Tamar be glad, -for her Lord came. * For her name proclaimed - about the Son of her Lord, * her appellation also - has called you $*$ to come to her.

The names of both Ruth and Tamar are interpreted symbolically as pointers to Christ through sound play. Ruth is said to have searched the "riches" of Christ. The biblical text (in the words of Boas) refers to her not seeking young men, whether rich or poor (Ruth 3:10). It is inferred from this that she was really looking for the riches of Christ. It so happens that "Ruth", the first word in the first line of stanza 12, contains the same consonants but in a different order as the word "riches" which is the last word of the same line. The name $r^{\text {' } w t ~ i s ~ t h u s ~ s y m b o l i c a l l y ~ i n t e r p r e t e d ~ a s ~ a ~ r e f e r e n c e ~ t o ~}$ the "wtr of Christ. In a parallel to this allusion, the name "Tamar" is given the same treatment in the second half of stanza 12. It is taken as a pointer to Christ, since it "proclaimed about the Son of her Lord" and "called" Christ to come to her. The link is provided through wordplay between $t m r$ and t'mry, a liturgical exclamation meaning "come, my Lord". Sound play and wordplay are thus used to provide a symbolic link between the heroines and Christ, "proving" their sincere interest in the procreation of the Messiah alone. 
It is because Ruth "saw" the high priest who was hidden in the loins of Boaz that she married him (stanza 15):

15. The coal which crept $*$ into the bed of Boaz - ascended and lay down. * She saw the high priest - who was hidden in his loins,* (she) the fire for his censer. - She hurried and she became $*$ the heifer (wife) of Boaz. - For you she bore * the fattened ox.

Her selfless act of dedication is described with the help of the antithesis "calf" versus "fattened ox". She "ran" to become the "heifer" (= wife) of Boaz so that she could give birth to a "fattened ox". This should probably be understood as metaphoric language for the huge sacrifice she made. It involved humiliation, but she was rewarded for this (stanza 16):
16. She gleaned wheat * out of love for you; - she gathered stalks of straw. * You quickly gave her - the reward for her humiliation. * For the ears of wheat, - a root of kings, * and for the stalks of straw, - the Sheaf of Life $*$ which issued from her.

The offspring from the union of Ruth and Boaz is thus understood as a sign from God that she was commissioned by him for this role. The reward for her deed was that she received a "root of kings" for the ears of wheat she gathered, and the "Sheaf of Life" (Christ) which issued from her as a reward for the stalks of straw which she collected. "Ears" form an antithesis to "root", since the two extremities of the stalk are involved. "Stalks of straw" similarly forms an antithesis to "Sheaf of Life", since the one is worthless and the other invaluable.

\section{Conclusion}

When this hymn was sung at the occasion of the commemoration of the birth of Christ in the Syriac-speaking Church, it served as a kind of sermon. It was a madrâšâ, a teaching song, based on Matthew 1, Psalm 110, Genesis 38, the Book of Ruth, and various other related biblical contexts. It was intended to instil awe in the minds of the listeners for the wonder of the human birth of God from a woman. Not only the response, which expresses explicit praise, but also other elements such as the note that "it is fitting" for Mary to experience "dread" for Christ (stanza 1) and epithets like "O Great Sea" (stanza 4), "O Triumphant One" (stanza 5), "O Victo- 
rious One" (stanza 6), and "O Honourable One" (stanza 8) would serve this purpose.

It was also designed to show the connection between the Old Testament prefiguration of Christ's coming and the realisation of this in the New Testament. The heroines mentioned in the genealogy of Jesus in Matthew 1 would serve as examples of believers from the old covenant who had the prophetic vision that the Messiah would be born from their offspring. Even the sound of the names of Tamar and Ruth would prove to be symbolic pointers to Christ.

As Old Testament types of Mary, women like Tamar and Ruth would also have served to answer criticism of the virgin birth by the Jewish contemporaries of Ephrem. Like Mary, these women were also ridiculed, but the boldness of their love for the Messiah-on whose behalf they offered themselves - was eventually rewarded and they were vindicated by God as holy women who were dedicated to Christ alone. This hymn would therefore have served also to inspire respect for their selfless dedication and spiritual insight. Their bold love would have been something which the men and women in the congregation would want to emulate.

\section{BIBLIOGRAPHY}

Beck Edmund (ed.), 1958

Des heiligen Ephraem des Syrers Hymnen de Nativitate (Epiphania). CSCO vol. 186/187, Scriptores Syri 82/83.

Botha, P.J. 1995

"Ephrem the Syrian's treatment of Tamar in comparison to that in Jewish sources". Acta Patristica et Byzantina 6, 15-26.

Brock, S.P. 1990

"A Brief Guide to the Main Editions and Translations of the Works of St Ephrem", The Harp 3/1\&2, 7-30.

Brock, S.P. 1992

The Luminous Eye. The Spiritual World Vision of Saint Ephrem the Syrian, Revised Edition. Cistercian Studies Series 124. Kalamazoo: Cistercian.

Den Biesen, Kees 1995

"Spreken over God bij Efrem de Syriër". Het Christelijk Oosten 47, 728.

Den Biesen, Kees 1998 
"Een kersthymne van Efrem de Syriër". Tijdschrift voor Liturgie 82/6, 330-340.

Den Biesen, Kees 2006

Simple and Bold. Ephrem's Art of Symbolic thought. Gorgias Dissertations 26, Early Christian Studies Vol. 6. Piscataway, N.J.: Gorgias Press.

Grundmann, Walter 1972

Das Evangelium nach Matthaüs, 3. Auflage. Berlin: Evangelische Verlagsanstalt.

Kronholm, T. 1991

"Holy Adultery. The Interpretation of the Story of Judah and Tamar (Gen 38) in the Genuine Hymns of Ehraem Syrus (ca. 306-373)". Orientalia Suecana 40, 149-163.

McVey K.E. 1989

Ephrem the Syrian, Hymns, translated and introduced, with a preface by John Meyendorff. New York: Paulist Press.

\section{NOTES}

1 Intended for liturgical use at the feast of Christ's birth and manifestation to the world, celebrated in Ephrem's time on 6 January. Cf. McVey's introduction in her book Ephrem the Syrian, Hymns, translated and introduced by Kathleen E. McVey, with a preface by John Meyendorff, (New York: Paulist Press, 1989), 29. For a short overview of the origin of the celebration of Christ's Epiphany, cf. Kees den Biesen, "Een kersthymne van Efrem de Syriër", Tijdschrift voor Liturgie 82/6 (1998), 330-340, especially 331-332.

2 Cf. Walter Grundmann, Das Evangelium nach Matthaüs, 3. Auflage (Berlin: Evangelische Verlagsanstalt, 1972), 61.

3 This can be inferred from the fact that Bathsheba is not mentioned by name, but is called "the wife of Uriah" (cf. Matt 1:6).

$4 \quad$ Cf. Grundmann, Das Evangelium nach Matthaüs, 62.

$5 \quad$ T. Kronholm, "Holy Adultery. The Interpretation of the Story of Judah and Tamar (Gen 38) in the Genuine Hymns of Ehraem Syrus (ca. 306-373)", Orientalia Suecana 40 (1991), 149-163.

Kronholm, "Holy Adultery", 158.

P. J. Botha, "Ephrem the Syrian's treatment of Tamar in comparison to that in Jewish sources", Acta Patristica et Byzantina 6 (1995), 15-26.

$8 \quad$ Kronholm ("Holy Adultery", 150) notes that the exposition of this story in Ephrem's hymns "deviates considerably from the more restrained and sober exegesis of Gen 38 displayed by Ephrem in his well-known prose 
commentary on Genesis and Exodus". He does remark that the Christological interpretation is the same in both genres, though.

Kees den Biesen, Simple and Bold. Ephrem's Art of Symbolic thought (Gorgias Dissertations 26, Early Christian Studies Vol. 6; Piscataway, N.J.: Gorgias Press, 2006).

Mary mentions the slander and persecution she had to cope with explicitly in the sixth hymn of this cycle. Cf. Edmund Beck (ed.), Des heiligen Ephraem des Syrers Hymnen de Nativitate (Epiphania) (CSCO vol. 186, Scriptores Syri 82, 1958), 51. McVey, Ephrem the Syrian, Hymns, notes (111 n.209) that "Jewish criticism of the virgin birth is an issue that constantly recurs in these hymns".

For a discussion of the role played by opposition and polarity in Ephrem's theology, cf. Den Biesen, Simple and Bold, 51-62. (Epiphania) (CSCO vol. 187, Scriptores Syri 83; 1958), 55-57. The text was edited in the accompanying volume, vol. 186, Scriptores Syri 82, 63-66. Kronholm, "Holy Adultery", 149-150.

14 Ephrem the Syrian, Hymns, 124-127.

15 The translation of J. B. Morris, Select Works of St. Ephrem the Syrian (Oxford, 1847) was based on the edition by Assemani. Cf. McVey, Ephrem the Syrian, Hymns, 29, n.123 for details. This particular hymn had the number 7 in the edition of Morris. It was later also taken over by J. Gwynn (ed.), Selections translated into English from the Hymns and Homilies of Ephraim the Syrian, in: A Select Library of Nicene and Post-Nicene Fathers, Second Series, vol. 13 (Oxford/New York 1898). For an overview of the various editions and translations of this collection, cf. S. P. Brock, "A Brief Guide to the Main Editions and Translations of the Works of St Ephrem", The Harp 3/1\&2 (1990), 7-30, especially 26.

McVey, Ephrem the Syrian, Hymns, 125 n.268 suggests "or "sunrise"" and refers to Nat. 1:6 where Ephrem says "the hidden light descended, and its beauty shone forth from a body; the dawn of which Zechariah spoke, lights up Bethlehem today" (translation of McVey, idem, 64). McVey notes (64, n.6) that Zech $2: 5$ is alluded to and that the word used here, $d n h$, and the corresponding symbolism of light is inextricably tied to Epiphany since $d n h$ means epiphany, manifestation.

17 Following the suggestion of Beck (CSCO vol. 186, 64 n.9) to read ' $y$ ty.

18 McVey, Ephrem the Syrian, Hymns, 126 translates this line as "A thirsty fount stole Your drink from its source". Kronholm's translation, "Holy Adultery", 149 is closer to the translation given here than that of McVey.

McVey, Ephrem the Syrian, Hymns, 126 translates "You she kept [in memory], and she became a chaste woman". As she notes, Beck has suggested that Ephrem possibly intended mqdšt' to convey the meaning of 
the Hebrew qedeřa, a "sacred [prostitute]", but this suggestion is not accepted by her or in this version. I have taken $n t r$ to mean "to preserve, to abstain" in this line, however, so that it means that Tamar could serve as an early representative of the Syrian proto-monastic ideal. Cf. also Botha, "Ephrem the Syrian's treatment of Tamar", 23. The last stich seems to confirm this: She was dedicated to Christ alone. Kronholm ("Holy Adultery", 149) renders this also with "she kept watch and became a hierodule. She was in love with You".

Kronholm ("Holy Adultery", 150) translates this stich as "The Son of her lord (sic) went in".

McVey explains this clever play on the similarity between Tamar's name and the liturgical exclamation "Come, my Lord!" ( $t$ ' mry). Cf. McVey, Ephrem the Syrian, Hymns, 127 n.276.

McVey has understood Ruth to be the subject of the verb ("She teaches boldness to all penitents"), but this is improbable in light of the masculine form. Cf. the use of hsypwt', "boldness", in Luke 11:8, the parable about perseverance in prayer.

According to McVey (Ephrem the Syrian, Hymns, 29), Ephrem himself collected Hymns 5-20 of the present collection and gave the title of "lullabyes" to it because most of them are sung by Mary to her Son.

For a discussion of the antithesis between speaking about God and keeping silent, cf. Kees den Biesen, "Spreken over God bij Efrem de Syriër", Het Christelijk Oosten 47 (1995), 7-28. The topic was taken up again in much greater detail in his book Simple and Bold, 103-206. The theme of Mary's addressing Christ is also found at the beginning of the sixth hymn in the cycle. Their special relationship is explored at length in the eleventh hymn of the same cycle.

Cf. also the comparison Mary makes between herself and Tamar in hymn 15 (stanzas 7 and 8) of the cycle. She is being slandered and despised, but will also be vindicated like Tamar.

"Hyssop" represents high priesthood, "a throne and a diadem" suggest kingship, and "family and descent" from Abraham summarise his human descent from the father of all believers. The three names mentioned and the qualities inherited from them form a parallel, with a chiastic arrangement of elements between the first (the divine aspect) and the last two (the human aspects).

27 Ps 110:4 is alluded to. Cf. also Heb 7:7-25 where the problem of Jesus' descent from Judah (which is not a priestly tribe) is resolved by reference to the "eternal" priesthood of Melchizedek mentioned in Ps 110:4.

This interpretation displays Ephrem's aptitude to identify binary pairs of opposites. It may be the only case in his work where the square of a number is used to create an antithesis! 
Cf. Ps 110:1.

30 Fear for the punishment proscribed by the Law is, of course, a display of fear of God.

31 Cf. the hymn De Ecclesia 9 and Kees den Biesen's very insightful and thorough discussion of this aspect in his book Simple and Bold, 109-146, especially 123 .

32 "All the voices because of the-voice-of-you".

33 De Ecclesia 9:8. The translation is that of Den Biesen, Simple and Bold, 125.

34 This would be the reason for the emphasis on the divinity of Christ in the first six stanzas and the many titles of praise given to him: "O Great Sea", "O Triumphant One", "O Victorious One", "O Honourable One", etc.

35 This is stated more explicitly in De Nat 15:6-8.

36 Cf. my article "Ephrem the Syrian's Treatment of Tamar", 23. Cf. also Sebastian Brock, The Luminous Eye. The Spiritual World Vision of Saint Ephrem the Syrian, Revised Edition (Cistercian Studies Series 124; Kalamazoo: Cistercian, 1992), 131-141 for a discussion of Syrian protomonasticism.

37 In another hymn, Nat 1:33, Ephrem interprets the red cord of Rahab in a similar way symbolically: Rahab longed for him; * for if the purple thread rescued her through the symbol from the wrath, * then she tasted reality in the symbol. 